\title{
KALINDAQDAQ TRADITION OF MANDAR COMMUNITY IN WEST SULAWESI: ISLAMIC EDUCATION STUDY BASED ON LOCAL WISDOM
}

\author{
Ridhwan ${ }^{1 \star}$, Sri Astuti A. Samad ${ }^{2}$, Khaeruddin Kiraman ${ }^{3}$ Gasan $^{1}$ \\ ${ }^{1}$ Institut Agama Islam Negeri Bone, South Sulawesi, Ind́onesia \\ ${ }^{2}$ Universitas Islam Negeri Ar-Raniry, Banda Aceh, Indonesia \\ ${ }^{3}$ Curtin University, Western Australia \\ *Email: ridhwan@iain-bone.ac.id
}

Received: September 13, 2021

Accepted: December 4, 2021

\section{Abstract}

Kalindaqdaq is a literary work of Mandar community which is considered as an old poetry and one of the actualizations of religion and local wisdom harmonization. Several studies on Kalindaqdaq have been conducted but none explores from ethno-pedagogical perspective. This study is aimed at supporting the importance of local wisdom in Islamic education because the education process cannot be separated from the expression of culture and customary orders proven to be capable of educating humans. This study employs a qualitative method with ethno pedagogical approach. The data are collected through a library research by identifying, selecting, and reviewing research outputs relevant to the topic and literary works about Kalindaqdaq. The analysis is conducted by finding out the integration or interconnection relationships of the local wisdom with education. The findings reveal that Kalindaqdaq functions as a means of religious education, morals, traditional socialization media, communication tools for traditional narratives and entertainment. Kalindaqdaq as a cultural product contains Islamic educational values, such as monotheism, worship, morals, social 
and heroism. The implication of this study derives from the findings. The findings imply that kalindaqdaq is important under an ethnopedagogical perspective, applicable in the educational process. This study is the evidence of Islam and local wisdom harmonization, which highly supports the development of Islamic education as an integral part of education in Indonesia.

Kalindaqdaq merupakan karya sastra masyarakat Mandar yang tergolong sebagai puisi lama dan dianggap sebagai salah satu aktualisasi harmonisasi agama dan kearifan lokal. Beberapa penelitian tentang Kalindaqdaq telah dilakukan tetapi belum ada yang mengeksplorasi harmonisasi pendidikan Islam dan kearifan lokal dengan perspektif etnopedagogis. Penelitian ini menggunakan metode kualitatif dengan pendekatan etnopedagogis. Signifikansi kajian ini adalah untuk menegaskan bahwa keberadaan kearifan lokal dalam pendidikan Islam menjadi penting karena proses pendidikan tidak lepas dari ekspresi budaya dan tatanan adat yang dapat mendidik manusia. Pengumpulan data dilakukan melalui studi pustaka dengan mengidentifikasi, memilih, dan mengkaji literature ilmiah yang relevan dengan topik penelitian dan karya sastra tentang Kalindaqdaq. Analisis dilakukan untuk mengetahui keterpaduan atau keterkaitan kearifan lokal dengan pendidikan. Temuan mengungkapkan bahwa Kalindaqdaq memiliki fungsi sebagai sarana pendidikan agama, moral, media sosialisasi tradisional, alat komunikasi untuk narasi tradisional dan hiburan. Kalindaqdaq sebagai produk budaya mengandung nilai-nilai pendidikan Islam seperti tauhid, ibadah, akhlak, sosial dan kepahlawanan. Implikasi dari penelitian ini berasal dari temuan. Temuan ini menyiratkan bahwa kalindaqdaq penting dari perspektif etnopedagogis, yaitu penggunaan kearifan lokal dalam proses pendidikan. Kajian ini merupakan bukti harmonisasi dan adat Islam serta mendukung pengembangan pendidikan Islam sebagai bagian integral dari pendidikan di Indonesia.

Keywords: Kalindaqdaq; Mandar custom; Islamic education; Local wisdom

\section{Introduction}

A study on Kalindaqdaq under ethnopedagogical perspective is highly crucial. The use of local wisdom in Islamic education is strongly recommended because the education process cannot be separated from the expression of culture and customary orders capable of educating human beings. Local wisdom is also a part of the socio-capital and cultural wealth of the region holding up the resilience of the nation. Ethno-pedagogical studies on harmony and integration of educational and religious values with local wisdom are crucial 
because ethno-pedagogy views local wisdom as a source of innovation and skills that can be empowered for community welfare.

Indonesians are plural and multicultural with various tribes, languages, and religions. Hundreds of thousands of ethnic groups become important sociocapitals and foundations for customs so that Indonesia becomes a culturally rich country. Each ethnic group has their own traditions and customs, one of the hardly ever explored traditions is the work of oral literature in modern and old literature. For example, in Java, we have Macapat, which is Javanese literature in the form of poetry which is heavily influenced by Islamic teachings (Mulyono, 2007; Sahlan and Mulyono, 2012). Sundanese also have rumpaka, a Sundanese Traditional song in Cianjur which can shape the local community character (Adawiah and Munsi, 2019; Ningsih and Hotimah, 2018). Malay in Riau, Bengkulu, even to Sambas West Kalimantan have a tradition of speech which is often called pantun. Pantun contains the values of religious education, morals, relationships to God, parents, and fellow human beings even to the nature (Hasbullah, 2014; Wiguna, et.al., 2017; Ritawati, 2018). Acehnese hold oral traditions containing advice and admonitions known as hadih maja (Irfan, et. al., 2019; Fakhri dan Faizin, 2017). In addition, Banjar have ungkapan (expressions), that contain educational values (Bahdiah, 2014). Gorontalo possess tuja'i, hudali and hudaya with highly influential educational values, for example, gratitude and sincerity, ethical, creative, obedience or loyalty, and decency (Lamusu, 2020; Djakaria, 2017). And, Mandar in West Sulawesi, uphold literary works in the form of old poems called Kalindaqdaq. Kalindaqdaq originally comes from the word kali (stuffing) and daqdaq (chest). Kalindadaq means the contents of the chest associated with the heart. The contents of the heart are extracted to be conveyed to the community (Nurhayati, 2013). Kalindaqdaq teaches the values of religious education, morality, and the meaning of life for the people of Mandar. Therefore, it becomes the most widely used literary works in religious rituals to date.

The literary works from various ethnic groups in Indonesia above are important cultural wealth of the Indonesian nation. It is a valuable social capital and cultural asset for the foundation of the development of the nation's character because local literary works do not only complement cultural customs and rituals but also provide educational values applicable for the development of the nation in the future (Didipu, 2012). Therefore, Sibarani (2012) and Samad (2015) affirms that local wisdom has an important role in the education and character building of the nation's generation.

el Harakah Jurnal Budaya Islam Vol. 23 No. 2, 2021 
The current study explores two main focuses, the role of Kalindaqdaq in Mandar culture and the Islamic educational values implied in Kalindaqdaq. Therefore, it discusses about the tradition of Kalindaqdaq under the perspective of Islamic education and local wisdom by using ethno-pedagogical theory.

\section{Islam and Adaq in Mandar}

Islam entered Mandar, West Sulawesi, in two stages. First, it happened in the 14th century through Muslim traders. They introduced Islam to the local community. The second stage occurred in the 16th-18th century, which was only through a contact between Islamic preachers and society. In the first stage, trading became a medium of spreading Islam, but this method was less effective because the main purpose of the Muslim traders was economic stability, not spreading the religion of Islam. However, the advantages of Muslim traders showed respect for tradition and respect for the king, which finally received the king's sympathy that the kingdom also provided protection and facilities to them (Kawu, 2011; Mukhlis and Usman, 2020). According to Lontaraq Balanipa (lontaraq is an ancient manuscript in Mandar, Bugis, and Makassar language), the entry of Islam in Mandar was pioneered by Sheikh Abdurrahim Kamaluddin, who was also known as Tosalamaq in Binuang.

Islamic dialectics and customs in the social system and cultural structure of Mandar community bring about harmonization. This can be seen from the phrase; "adaq makkesaraq, saraq makkeadaq, naiya saraq adaq nala gassing, naiya adaq saraq nala suro, matei adaq muaq andiang saraq, matei tio saraq muaq andiang adaq" [The custom is integrated in shari'a, the shari'a merges in the custom, the shari'a is the custom made a force, while the shari'a custom is made a demand, the custom will die if there is no shari'a, as well as the shari'a will die if there is no custom] (Idham, 2013).

Slowly, Islam is easily accepted as a religion by Mandar community in the majority. According to Ismail (2012), Islam is easily accepted by Mandar because of three factors: first, Islamic teachings are seen as the value of truth; second, Mandar people have religious seeds, namely aspects of belief and ritual practice; third, Islam has similar teachings to the old beliefs adhered to, such as believing in the unseen and the ghosts.

Mandar society is socio-religiously similar to the majority of Indonesian Muslims. They adhere to ahlu Sunnah wal jama'ah in aqidah and Shafi'i sect in fiqh practice. While in Sufism, many of them follow Imam al-Ghazali while in the order, they belong to mu'tabarah called Qadiriyah, Naqshabandiyah, and 
Khalwatiyah. An adherent of Sufism is Qadiriyah who links his sanad (a list of authorities who have transmitted a hadith) to the great cleric (ulama), Abdul Qadir Jailani born in Tabariztan (d. 1166 BC). Tarekat Qadiriyah is taught by Annangguru Muhammad Shaleh (d. 1977 BC), a student who directly receives a sanad from Syekh Alwi al-Maliky al-Husaini (d. 1971 BC) upon learning in Makkah (Mukhlish, 2020).

\section{The Life Philosophy of Mandar}

Mandar society must know the essence of passemandaran, which is the top value in the philosophy of "mesa ponge'pallangga" (aspect of divinity), Da'dua tassisara' (legal and democratic aspects), tallu tammalaesang (economic, justice, and unity aspects). Related to the criteria of a noble human being (tau piya) in the philosophy of life, Mandar was not determined by his blood and descendants but by the nature and behavior (sipa' anna' gau). This is affirmed by Puang Dipojjosang, the second (II) I Pasu tau Tajibarani, who declares in front of Tomepayung, one of the Maraqdiya Balanipa, "I Ita' to Mandar cera' mappammula sipa' mappaccappurang di sesena tau piya tonganan [we are the people of Mandar state that blood criteria only at the beginning and it is the character that determines in the end for people who have virtue].

The most important is the application of cultural value in the expression 'Loa mappa'bati' di ada' (words are reflected in the custom), ada'mappa'bati'di kedo (custom is reflected in the deed), Kedo mappa'bati'di gau' (actions are reflected in the behavior), Gau' mappa'bati' di tau (behavior reflected to others), Tau mappa'bati' di siri' (human beings reflected in the siri'), Siri' mappa' batik di lokko' (siri' reflected in dignity and deep self-esteem) (Idham, 2007: 118), ta' to Mandar cera' mappammula sipa' mappaccappurang di sesena tau piya tonganan (we are Mandar, the creiteria for blood is only in the beginning and it is the nature that determines in the end for people who have virtue). Aslo, the practice of the following expressions, Loa mappa'bati' di adaq (word are reflected in customs), Adaq mappa'bati'di kedo (customs is reflected in actions), Kedo mappa'bati'di gau' (action are reflected in behavior), Gau' mappa'bati' di tau (behavior is reflected in others), Tau mappa'bati' di siri' (humans are reflected in iri') Siri' mappa' batik di lokko' (siri is reflected in deep dignity and self-respect) (Idham, 2007: 117-118).

Darmawan Mas'ud, a Mandar historian and culturalist, explained that siri' and lokko' in Mandar social and cultural system which means "shame" is the most important part of people's lives. If lokko' and siri' missed from someone,

el Harakah Jurnal Budaya Islam Vol. 23 No. 2, 2021 
he is similar to an animal, and if there is still lokko' and siri' within a person, he is a real human being (Mas'ud, 2015). For Mandar, religion, customs, sharia, honesty and shame (siri') are the philosophy of life. Religion becomes the foundation of belief, harmony of customs and sharia in social order, honest behavior and shame as a trait attached to every Mandar. Even, the term siri' (shame) is also known in the term of Bugis and Makassar, symbolizing the philosophy and character of people of Sulawesi in general.

The core of the life philosophy of Mandar can be fundamentally understood as socio-cultural values used by the supporting community as a pattern or patron in daily activities. The normative value is still attached to Mandar society whose implementation becomes the soul or spirit in deciding mindset and stimulating actions in society. In the tradition and culture of Mandar, Bugis, and Makassar, these values encourage work ethic, character, personality over the existence of ethics. This indigenous culture is still maintained, and it becomes the central point of Mandar, Bugis, and Makassar, which essentially reaches all aspects of human life (Amri, 2017).

Mandra (2001) explains that in the cultural context, the community customs are always imbued by the religion embraced in the community. This is evident from the whole philosophy of life in Mandar, both written in lontaraq and developed in the community. Correspondingly, related to the philosophy of life, Mandar are known as fishing communities along the coastline of the Makassar Strait, so they also have a strong maritime cosmology (Sunarti, 2017: 33; Nurkholis, 2018). According to Alimuddin (2013), the Mandar tradition is popular for its boats Sandeq, the fastest outrigger boat in the archipelago ever sailed to the United States. It is like the Bugis people who are famous for Pinisi boats, a traditional boat capable of sailing all the way to Vancover, Canada, and Australia.

Wander or sumobal in Mandar language, means to leave home in search of a more decent life. In Bugis language, it is called masommpe'. According to Perlas, (1996), Hamid, (2004) and Patji (2009), the tradition of odyssey has become a part of the lives of Mandar, Buginese, and Makassar who do diaspora and migration to various regions in Indonesia and abroad. Therefore, it is easy to find such ethnic communities around coastal areas in Malaysia, Singapore, Riau, Bangka, Pontianak, Seribu Islands (Jakarta), Karimun Jawa, Kangean, Bali, Alor, and in the islands of East and North Kalimantan.

\section{Method}

el Harakah Jurnal Budaya Islam Vol. 23 No. 2, 2021 
This study employs qualitative method with ethno pedagogical approach. It explores the harmonization of local tradition and Islamic education. The data were collected through a library research by identifying, selecting, and reviewing books, journal articles, and other research outputs relevant to the research topic. The analysis was conducted by finding out the integration or interconnection relationships of the local wisdom, Kalindaqdaq, with Islamic education.

The application of paradigm and integration dialogue in Islamic sciences is prominent to discuss considering that the practice of religious education constantly applies conflict and independent paradigms. These paradigms have a great influence in the formation of religious viewpoints, both socially and culturally. The relationship between Islamic sciences in one side and with natural, social, and cultural sciences on the other side requires a pattern of integrated or interconnection relationships and dialogues. Islamic studies require a multi-disciplinary approach, both interdisciplinary and transdisciplinary. Scientific linearity that restricts the field of science narrowly and monodisciplines will lead to unrelated religious understanding and irrelevant religious interpretation to the context of the study. A new model of religious thought that encourages independent dialogue and discussion on subjective, objective, and intersubjective aspects of science and religion will create a new model of religion in the multicultural era (Abdullah, 2012).

One of the efforts that can be made to apply integrative paradigms and interconnections in Islamic education is an ethno-pedagogical approach. Ethno-pedagogy views that local knowledge or wisdom is a source of innovation and skills that can be empowered for the welfare of the community. That way, teachers and students will build a quality education that can produce high-quality resources, who are expert, skilled, creative, productive, positively behaved, and who love the culture, homeland, and country (Syasmita, 2019).

\section{Discussion}

Kalindaqdaq includes folk poetry (oral folklore) bound by certain conditions (fix phrase). This folk poem is a predetermined literature form, usually consisting of several series of sentences (Dananjaya, 1991). Kalindaqdaq is a mixed expression (pau-pau) from Malay culture which contains a rhythm structured from Malay culture, which is also similar to poetry to resemble it through either diffusion, acculturation, or assimilation (Harisa, 2021).

el Harakah Jurnal Budaya Islam Vol. 23 No. 2, 2021 
From a historical perspective, there found no clear record of when Kalindaqdaq is created and who made it? However, like other oral traditions in various ethnicities in the archipelago, Kalindaqdaq continues to be used and preserved by Mandar people until now. Nevertheless, a manuscript Lontaraq Pattapingang mentions that it is a kind of unknown-author local literature. Furthermore, nowadays people are free to create, copy, or modify it in Mandar language (Yasil and Darwis, 2017).

In Arabic, daqdaq is derived from the word qaldan which means spinning. This word is associated with spinning a thread, and spinning it requires prudence. That's how kalindandaq requires prudence. In addition to the word qaldan, there is the word qallidun which means warehouse. This word is attributed to storage. If it is connected with Kalindaqdaq, it refers to the storage of various sciences and policies. Also, there is the word qalaaid which means necklace. Necklaces are women's jewelry. If associated with Kalindaqdaq, it has beautiful words and beautiful meanings. However, the content of Kalindaqdaq can also be innuendo and ridicule (Nurhayati, 2013).

The kinds of Kalindaqdaq are: Kalindaqdaq masaalah (Religion), Kalindaqdaq tomawuweng (parents), Kalindaqdaq naqimuane (Youth), Kalindaqdaq naqibaine (girl), Kalindaqdaq nanaeqe (children), Kalindaqdaq pepatudhu (advice), Kalindaqdaq pangino (humor), Kalindaqdaq paella (satire), Kalindaqdaq sipomengeq (romanticism), Kalindaqdaq sipakaingaq (social criticism), Kalindaqdaq macca (obscenity) (Idham, 2013: 209-210). Kalindaqdaq functions as a means of education about morality, ethics and religion, media dissemination of custom information, complementary traditional ceremonies, traditional communication tools, and entertainment. Nevertheless, it is recognized that kalindaqdaq is one of the most widely used types of literary works by Mandar people in religious events, traditional rituals, and cultural processions (Idham, 2013). Recently kalindaqdaq is delivered in traditional events, such as totamma mangaji, sayyang pattu'du, and today many use it as lyrics Mandar song.

Meanwhile, totamma mangaji is a customary ritual when a child who has finished reciting the quran. The tradition of sayyang pattu'du' is one of the rituals usually combined with totamma mangaji. Sayyang pattu'du' which literally means a dancing horse, performed by a child who finishes the recital. $\mathrm{He}$ is brought on parade around the village on horseback. The time of its implementation is usually in the month of the prophet Muhammad's birthday or on August 17, Indonesia's Independence Day. At this time, the customary 
rituals of Kalindaqdaq temples are performed by the parrawana. Some people accompany horses dancing while beating tambourines.

The form of Kalindaqdaq is almost the same as the Malay pantun, which also has four arrays. Generally, the first array contains eight syllables; the second array has seven syllables; the third array has five; and the fourth one has seven syllables. However, it is believed that Kalindaqdaq is a Mandar tradition that contains education, which can increase religious beliefs, meanings of life, good behavior. Thus, it can raise cultural resilience, peace and unity and a sense of nationality (Harisa, 2021). According to Idham (2007), Nurhayati (2013, 2016), and Darmawati and Sahabuddin (2019), Kalindadaq contains educational values that can be described as follows:

\section{Tawhid Education}

Tawhid is the essence of Islamic teachings. Upon Islamic learning, everything will start from the discussion of tawhid, for example, faith in Allah, the prophet and the book, the judgment day, the good and bad destiny. Kalindaqdaq contains the values of tawhid to Allah Almighty, that we usually find in Islamic teachings or parents' advice to the children (Hakim, 2012). The teachings of tawhid explain about Allah as God to worship, the Prophet Muhammad (PBUH) as His Messenger to believe and follow. God as the purpose of life, intangible, omnipotent, loving and compassionate. The following is one of the examples of Kalindadaq with those teachings:

Pennassai sahadaqmu

Mesa Allah Taala

Nabi Muhammaq

Suro to matappa-Na.

[Make your confession of faith clear

The Only One God Almighty

Prophet Muhammad

His trusted Messenger.]

The sentences in Kalindaqdaq above explain the teachings of tawhid, by the Mandar people called Kalindaqdaq masaallah. It overviews that the existence of Kalindaqdaq actively provides understandings to the people of Mandar about the importance of beliefs to uphold and obligations to fulfill as Muslims considering the people of Mandar are loyal in general (Darmawati and Sahabuddin, 2019). According to Hakim (2012), some examples of 
Kalindaqdaq masaalah containing tawhid education in the teachings of Imam Lapeo are as follow;

Ia lamba uitai

Lamba ugulilingngi

Imakke nyawa

Iqdai makke tau

[That I'm going to find

Go, I'll go around

Is the All-Beneficent Substance

He is intangible man]

Allah Taala sisanna

Andiang daqduanna

Puang Kuasa

lino annaq aheraq

[Only the One God

The One and Only

Almighty God

The world and the hereafter]

Allah Ta'ala nisomba

Andiang daqduanna

Nabi Muhammad Suro nibole-bole

[God who worshipped

The one and only

Muhammad, His beloved Messenger]

Allah Taalapaulle

Lino lambiq aheraq

Puang paqdappang

[Almighty God

From the world to the afterlife

The Forgiving Lord]

The Most Merciful God

The obove Kalindaqdaq is sourced from the teachings of Annangguru Muhammad Thahir (w. 1952), entitled Tosalamaq Imam Lapeo, Campalagian, Polewali Distric, Mandar. He was a well-known and famous cleric during the disciple of Sheikh Hasan bin Alwi Jamalullail, a cleric of Yemeni descent, born in Lasem, Rembang, Central Java. Syekh Hasan later settled in Pambusuang, Polewali Mandar, spread the Islamic religion there, and become a teacher 
of Imam Lapeo (Zuhriah, 2013). This Kalindaqdaq is used by a scholar or teacher who teaches tawhid to his students, and also by parents who instill the values of tawhid to their children that Allah is the one and only God, and the Prophet Muhammad is His trusted messenger.

\section{Worship Education}

The command to worship is the second major element, after a person holds tawhid. The command of worship can be seen in the pillars of Islam and the most important thing is prayer. Therefore, in educating children, parents usually use Kalindaqdaq. In general, parents do not directly reprimand or advise their children so that they will be more touched by Kalindaqdaq (Nurhayati, 2013: 85). The following stanzas explains how Kalindaqdaq teaches about worship:

Sahadaq anna sambayang

Sakkaq anna puasa

Maqhaji toqo

Rokonna asallangan

Ajappui tongan-tongan

Rokonna asallangan

Pepattomoqo di kittaq sara assa

Syahadat and prayer

Zakat and fasting also hajj

Pillars of Islam

Understand the truth

Pillars of Islam

Then look

In the book of lawful sharia

According to Idham (2013: 211), the stanzas above are included in Kalindaqdaq masaalah which explains the problem of worship. Kalindaqdaq masaalah contains the pillars of Islam, which are shahadat, prayer, fasting, zakat and hajj. But the stronger emphasis on worship is prayer, as mentioned in the following Kalindaqdaq:

Sambayang ditiaq tu-uq

Namaka di pesulo

Kedo macoa

Namaka di pekasor

Prayer is the best

el Harakah Jurnal Budaya Islam Vol. 23 No. 2, 2021 
Made a torch in the dark

Noble work

Suitable provisions for mattresses

Tandi soppoi sambayang

Tandi teweq-i jeqne

Iyamo tiaq Maparri di pogau

No prayers will be carried

Will not be allowed wudhu

That is why it is hard to do

Kalindaqdaq above warn children or someone that the prayer is not heavy. The five-time prayer instruction was received by the Prophet Muhammad to perform as a provision in the hereafter. If the they still do not care about the advice of the parents to pray, the parents will continue the kalindaqdaq above. Usually, children listen to the dark grave. A child will listen to the kalindaqdaq above and they usually perform the prayer immediately. Kalindaqdaq is highly effective to warn five-time prayers. It is the education of worship that a parent does to his children.

\section{Moral Education}

Morality or akhlak for Mandar society is the most essential element. In Mandar, akhlak is called gau' atau sipaq, which is closely related to the word siri' and lokko' (shame). It can be seen in Kalindaqdaq below:

Padiangi pakaiangyang siri'mu

Mannassa iya tu'u siri', sipaq mappasillaengan tau anna olo-olo

Olo-olo mau saicco' siri'na tandiang,

Make sure that you have high self-esteem,

For it is self-esteem that distinguishes between humans and animals

Animals have no shame,

Therefore, one who has no shame, like an animal

Ingarani pasang to mendiolota

Damelo nisanga, dao losong

Anna dao pa'itai akkeimangan

Remember the ancestral message: don't be arrogant

Do not lie and do not pursue positions

Pakatunai alawemu lao di annanggurummu, dibatanadi tumbur apiangan

el Harakah Jurnal Budaya Islam Vol. 23 No. 2, 2021 
You should respect your teacher

because it is the source of goodness

Da pendai di mesa boyang

mua' sangga towaine diaya

da to'o pole palli'ai pallolor

do not let a man enter the house,

if only a woman within,

don't be visiting past pallolor (living room boundary with family room)

The several stanzas of Kalindaqdaq above reveals about siri' (shame), sipaq (behavior), which is the essence of the morality of Mandar people. When it comes to religious teachings, shame is the most important part of religion. Prophet Muhammad said, "shame on some of the Faith" (Bukhari and Muslim). The applications of siri' in Kalindaqdaq is that Mandar will be ashamed if they are showing arrogant, lying, pursuing positions, disrespecting teachers, and behaving despicably on women.

\section{Heroism Education}

Mandar, like other areas, also participated in fighting for independence against colonialism. Therefore, in the history of the massacre, 40,000 people in the Galung Lombok, an event was carried out by Westerling (Netherlands) in Polewali Mandar Regency. It raised the spirit of heroism and patriotism from various circles, from either the common people or Maraqdia and his descendants. Kalindaqdaq that reveals heroism is known as Kalindaqdaq Pettomuaneang. According to Adawiah and Srimusdikawati (2019), if viewed from the contextualization of the text, kalindaqdaq indicates three characters a leader should have; sincerity, consistency, and assertiveness. The actualization process involves several contexts. The sentence bannang pute (white thread), lango-lango (dye), derived from the context of weaving silk sarongs, then drawn into a new context of patriotism to describe the character of a patriotic leader.

Inditia tommuane

Bannang pute sarana

Meloq dicinggaq

Meloq dilango-lango.

Here comes the knighthood

Problems like white thread

Willing to be dyed 
Given a pink color.

The Kalindaqdaq above communicates the knighthood of a Mandar man likened to a white thread willing to be dyed in pink (blood). Here is the kalindaqdaq that explains about a knight who does not back down in facing the problems.

Minangi kaccang tunggara

Minangngi disombalang

Dotai ruppu

Dadi lele tuali.

The stronger southeasterly winds

The more developed the screen

Better ruined

Instead of receding back.

Dotai tau simateang mie'

Na membere di olona lita'

Dadi nanaparenta tedong pute to kaper

It is better to die to the ground

Rather than to be ruled by the white buffalo (Dutch) the heathen Mua' diang nawaccowa manggeser nagarata

Dotami tau sipettobangan ceraq,

Asayanggi nagarata siola paqbanua,

Mua na disurung dituyuq para tappaq

If anyone is going to interfere with our country

Better die bathed in blood,

Love our country with all the people

Although it will make us die to the ground

The heroism in leadership is perceived similar to the process of weaving the scabbard. Not only prudence, a good leader must be creative. The process of contextualization and actualization in kalindaqdaq poetry concludes that Mandar tribe has high progress and cognitive abilities in language, literature, and logic (Adawiah and Srimusdikawati, 2019).

Mandar societies, both male and female, have a heroic nature. It is no wonder that Mandar has a female fighter, Andi Depu (1907-1985) who holds the title of great Mother. Andi Depu is a Maraqdiya (King) 52nd, he succeeded his father Andi Baso who died earlier (Mandra, 2015. Andi Depu was a female fighter who fought against the Dutch despite badik (traditional rail weapons) and weapons affixed to her neck and still waving the Red and 
White flag in Tinambung when the Japanese entered the land of Mandar. Because of her struggle, she was awarded a National hero in 2018 during the time of President Joko Widodo and awarded the Bintang Maha Putra award by President Sukarno.

According to Hamid (2016), the heroic nature and patriotism of Mandar must be paid dearly to defend Indonesia's independence by killing tens of thousands of lives (Galung Lombok event). In February 1947, Mandar who carried out the fight were accused of being murderers, robbers and extremists who were later killed without legal process by the Dutch. In this context, there is a dialectic between nationalism, religion, and culture that is at least implemented in Kalindaqdaq Pettomuaneang (patriotism).

\section{Social Education}

One of the attributes and characters that stand out in the ethnic groups in the archipelago is the existence of strong social ties and solidarity. Social bonds are reflected not only in ritual traditions but also in oral and literary traditions or manuscripts. Mandar also have a philosophy of life that contains a symbol of strong social ties in Kalindaqdaq. For example;

Diang sara disiolai

rio disiolai

anna' da tau sipattau laengan

There's a problem we're having together,

joy is also shared,

so that we avoid the attitude of division

mua' melo'o naelo'i tau

pecoai turang paummu,

agu anna kedo

if you want to be liked by people,

fix your words

your attitude and behavior

tau biasa manttinro barang-barang

anna iya tau malaqbiq

ma'itai atonanganan

Ordinary humans are the ones chasing treasures

while the noble man

is seeking the truth

el Harakah Jurnal Budaya Islam Vol. 23 No. 2, 2021 
The phrases in Kalindaqdaq above mentions the word sara, rio dan disolai. Sara means a question or problem, rio means joy, and disiolai means to be borne and enjoyed together. It means that, in society, the problems and favors must be enjoyed together. If the social life can run, the community will bring about strong solidarity. In addition, there is a word turang paummu, agu anna kedo, which refers to your speech and your attitude and behavior, and ma'itai atonanganan find out the truth. Speech, attitude, behavior and consistence with the truth is a foundation that can strengthen social ties and solidarity within society. It is in line with the words of the prophet (s). God does not look to your looks and your possessions, but He sees your hearts and deeds. (NB. Muslim). Charitable deeds or noble behaviors are reflected in one's speech, attitude, behavior from the heart that tends to goodness and truth.

The tradition of Kalindaqdaq, which is a part of local wisdom in Mandar society, contains educational values, such as tawhid, worship, morality, heroism, and social education. Local wisdom in Islamic education has an important meaning because the educational process cannot be separated from cultural repression and customary patterns proven to be effective in educating people.

Kalindaqdaq which is a part of cultural wealth can support cultural resilience. Cultural resilience strongly strengthens the resilience of the nation, which is a key prerequisite in today's world competition. Kalindaqdaq is also a proof of harmonization of Islam and customs, and it can support the development of Islamic education as an integral part of education in Indonesia. Therefore, the preservation of kalindaqdaq is prominent so that the values of Islamic education based on local wisdom can remain and be well applied in the community.

\section{Conclusion}

Mandar in the western part of Sulawesi holds customs heavily influenced by Islam. The scholars who came to teach Islam could provide a harmonious understanding between religion and customs so that the popular principle is "adaq makkesaraq, saraq makkeadaq", which means that the custom is integrated in sharia, sharia fused in custom. It influences the life philosophy of Mandar, which is the firmness of religion, harmonization between customs and sharia, one word with deeds and having shame (siri' and lokko'). Religion becomes the foundation of belief, harmony of customs, and sharia in social patterns, honest behavior, and shame as a trait inherent to every Mandar. One of the actualizations of the harmonization of religion and customs is Kalindaqdaq. 
The results reveal that Kalindaqdaq is a local cultural expression of Mandar which functions as a means of education about morality, ethics, and religion; dissemination media of custom information; complementary traditional ceremonies, traditional communication tools and entertainment facilities. Furthermore, Kalindaqdaq contains educational values, such as tawhid, worship, morality, heroism, and social education integrated and in harmony with Islamic education.

Kalindaqdaq is important in the ethno-pedagogical perspective, namely the use of local wisdom in the educational process. Kalindaqdaq is also a proof of harmonization of Islam and customs and can support the development of Islamic education as an integral part of education in Indonesia. Therefore, the preservation of Kalindaqdaq is highly recommendd so that the values of Islamic education based on local wisdom can remain and be well-applied in the community.

\section{References}

Abdullah, M.A. (2012). Religion, Science and Culture: An Intregrated, Interconnected Paradigm of Science, al-Jami'ah, 52 (1), 175-203. doi:/10.14421/ajis.2014.521.175-203.

Adawiah, R. \& Srimusdikawati, (201). Contextualization and Entextualization Mandarese Patriotism in Kalindaqdaq Pettomuaneang Performance, alAdabiyah, 19, (1), 1-19. doi:/10.24252/jad.v17i119i1a1.

Adawiyah, A. \& Munsi, M. F. (2019). Character Values Represented in Tembang Sunda Cianjuran, Indonesian Language Education and Literature, 5, (1), 1-16.doi: 10.24235/ileal.v5i1.3590.

Alimuddin, M.R. (2013). Sandeq: Perahu Tercepat Nusantara, Jakarta: Ombak.

Amri, (2017). Makna Simbolik Bentuk Ragam Hias Sarung Tenun Sutera MandarلDi Polewali Mandar, Laga-Laga, 1 (2), 165-176. doi/10.26887/ lg.v1i2.254.

Azra, A. (2005). Jaringan Ulama: Timur Tengah dan Kepulauan Nusantara Abad XVII E⿱ XVIII, Jakarta: Kencana.

Danandjaya, J. (1991). Folklor Indonesia, Jakarta: Pustaka Utama Grafiti.

el Harakah Jurnal Budaya Islam Vol. 23 No. 2, 2021 
Darmawati, B. \& Sahabuddin C. (2019). Kalindaqdaq: A Medium of Mandarese Character Building, Proceedings of the $28^{\text {th }}$ Internastional Conference, Universitas Syiah Kuala, Banda Aceh, July, 11-13, 882-830.

Didipu, H. (2012). Suatu Daerah: Konsep Dasar dan Ancangan Penelitiannya, Jakarta: Dapur Buku.

Djakaria, S. (2017). Tahuli dan Tahuda: Tradisi Lisan dan Pembentukan Karakter Bangsa di Masyarakat Gorontalo, Patanjala, 9 (2), 147-162. doi/10.30959/patanjala.v9i2.32.

Fakhri \& Faizin, M. (2017). Pesan-Pesan Dakwah dalam Hadih Maja, al-Bayan, 23 (2), 263-295.doi/10.22373/albayan.v23i2.2498.

Hakim, Z. (2012). Nuansa Tasawuf Imam Lapeo Dalam Kalindaqdaq Mandar: Kajian Hermeneutika, Sawerigading, 18, (1), 15-24. doi/10.26499/sawer. v18i1.332.

Hamid, A. (2004). Passompe: Pengembaraan Orang Bugis, Makassar: Pustaka Refleksi.

Hamid, A. (2005). Syekh Yusuf: Seorang Ulama, Sufi dan Pejuang, Jakarta: Yayasan Obor Indonesia.

Hamid, RA. (2016). Nasionalisme dalam Teror di Mandar tahun 1947, Paramita, 26 (1), 95-105. doi/10.15294/paramita.v26i1.5149.

Harisa, R. (2021). Kaindaqdaq in Tradition of "Sayyang Pattudu" in Polewali Mandar Regency (Study of Islamic Values), Journal of Reseach and Multidiciplinary, 4, (1), 417-422.doi/10.5281/jrm.v4i1.48.

Heriawan, A. et.al., (2018). Kajian Etnopedagogi: Seba dalam Masyarakat Baduy, Hermeneutika, 4 (2), 47-57. doi/10.30870/hermeneutika.v4i2.4831.

Idham, (2007). Sosialisasi Nilai Budaya Mandar (Studi Kasus pada Generasi Muda di Kec. Balanipa Kabupaten Polewali Mandar, Sulawesi Barat), al-Qalam, 20, (2), 115-131. doi/10.31969/alq.v13i2.568.

Idham, (2008). Local Wosdim: Benang Untaian Mutiara Hikmah Dari Mandar Sulawesi Barat, Makassar: Nuqtah.

Idham, (2013). Rukun Islam dalam Kalindaqdaq, Sawerigading, 19, (2), 207-216. doi/10.26499/sawer.v19i2.430. 
Irfan, A. Safriana, \& Yacoeb, M. (2019). Etnopedagogy Dalam Membentuk Karakter Siswa Pada Pendidikan Berbasis Madrasah, Dedikasi Pendidikan, $4(1), 1-9$.

Ismail, A. (2012). Agama Nelayan: Islam Lokal di Tanah Mandar, Yogyakarta: Pustaka Pelajar.

Kawu, A.S. (2011). Sejarah Masuknya Islam di Majene, al-Qalam, 17 (2), 151-162.

Lamusu, S.A. (2020). Kearifan Lokal dalam Sastra Lisan Tuja'i pada Upacara Adat Pingangan Masyarakat Gorontalo, Litera, 19 (3), 505-520. doi/10.21831/ltr.v19i3.32400.

Mandra, A. M. (2015). Transliterasi dan Terjemahan Lontar Balanipa Mandar, Makassar: Kretakupa.

Mandra, A.M. (2001). Beberapa Kajian tentang Budaya Mandar, Sendana Majene: Yayasan Saq-Adawang.

Mas'ud, D. (2015). Puang dan Daeng: Sistem Nilai Budaya Orang Balanipa Mandar, Surakarta: Zadahaniva.

Mulyono, (2007). Kajian Nilai Pendidikan Islam dalam Teks Tembang Macapat (Studi Nilai Pendidikan Islam berbasis Budaya), El-Harakah, 9 (2), 117133. doi/10.18860/el.v9i2.4648.

Muslim, A. (2016). Simbol pada Makam Syekh Bil Ma'ruf dan Sosio-Religi Pulau Tanggatangga Sulawesi Barat, Lektur Keagamaan, 14 (2), 257-280. doi/10.31291/jlk.v14i2.501.

Ningsih, N. D. \& Hotimah, H.H. (2018). Kajian Semiotik dan Etnopedagogik dalam Rumpaka Tembang Sunda Cianjuran, Pena Literasi, 1 (2), 81-91. doi/10.24853/pl.1.2.81-91.

Nurhayati, S. (2013). Kalidaqdaq Sebagai Sarana Berkomunikasi Masyarakat Mandar Sulawesi Barat, Indonesia, Prosiding Seminar Antarabangsa Ke-2 Arkeologi, Sejarah Dan Budaya Di Alam Melayu, Universiti Kebangsaan Malaysia, Bangi 26-27 November.

Nurhayati, S. (2016). Kalindaqdaq (Puisi Mandar) Sebagai Sarana Pendidikan Agama Bagi Masyarakat Mandar, Prosiding Seminar Internasional, Lampung, 24-26 September, 392-405.

el Harakah Jurnal Budaya Islam Vol. 23 No. 2, 2021 
Nurkholis, A. (2018). Mengenal Pusat Kabudayaan Maritim: Suku Bajo, Suku Bugis, Suku Buton, Suku Mandar di Segitiga Emas Nusantara, Doi: 10.31227/osf.io/t2xup.

Parman, A. et.al. (2010). Sejarah Islam di Mandar, Jakarta: Puslitbang Lektur dan Khazanah Keagamaan Badan Litbang dan Diklat Kementerian Agama.

Patji, A.R. (2009). Makassar Nama Kolektif: Masyarakat Migran Sulawesi Selatan di Alor Kecil, Kabupaten Alor, Nusa Tenggara Timur, Masyarakat dan Budaya, 11, (2), 151-176. doi/10.14203/jmb.v11i2.241.

Perlas. C. (1996). The Bugis, Oxford: Blackwell Publishers Ltd.

Ridhwan, (2017). Development of Tasawuf in South Sulawesi, Qijis, 5, (2), 39-46. doi/10.21043/qijis.v5i2.2412.

Ritawati, T. (2018). Pantun in the text of Nyanyian Lagu Melayu Asli (NLMA), Harmonia, 18 (1), 97-106. Doi: 10.15294/harmonia.v18i1.15524

Ruhiyat, (2017). Tradisi Sayyang Pattu'du di Mandar (Studi Kasus Desa Lapeo), Studi Agama dan Masyarakat, 13, (1), 1-26. doi/10.23971/jsam.v13i1.582.

Sahlan, A. \& Mulyono. (2012). Pengaruh Islam Terhadap Perkembangan Budaya Jawa: Tembang Macapat, El-Harakah, 14 (1), 101-114.doi/10.18860/ el.v0i0.2196.

Samad, S.A.A. (2015). Character Education Base on Lical Wisdom in Aceh (Study on Tradition of Children in Aceh Community), Al-Ulum, 15 (2), 351-370. Doi: 10.30603/au.v15i2.206.

Sibarani, R. (2012). Kearifan Lokal: Hakikat, Peran dan Metode Tradisi Lisan, Jakarta: Asosiasi Tradisi Lisan.

Sunarti, S. (2017). Kosmologi Laut dalam Tradisi Lisan Orang Mandar di Sulawesi Barat, aksara, 29 (1), 33-48. doi/10.29255/aksara.v29i1.99.33-48.

Syahrin, A.A. \& Mustika, B. (2020). Etnopedagogi Berlandaskan Nilai-Nilai Rumah Betang dalam Pembelajaran Sosiologi, Entita, 2 (2), 198-216. Doi: http://dx.doi.org/10.19105/ejpis.v2i2.3923.

Syasmita, I. (2019). Pendekatan Etnopedagogi Upaya Membangun dunia Pendidikan di Era Revolusi 4.0, Prosiding Seminar Nasional Fakultas Ilmu Sosial Universitas Negeri Medan, (3), 748-751. 
Yasil, S. (2004). Ensiklopedi Sejarah, Tokoh, Dan Kebudayaan Mandar, Makassar: LAPAR dan Forum Studi dan Dokumentasi Sejarah dan Kebudayaan Mandar.

Yasil, S. \& Darwis, M. (2017). Language Style on the Kalindaqdaq Poem (Introduction of Stylistic Study of Mandar Regional Literature), International Journal of Scienceand Research, 6 (9), 1795-1798.

Zuhriyah, (2013). Jejak Wali Nusantara: Kisah Kewalian Imam Lapeo di Masyarakat Mandar, Yogyakarta: Pustaka Ilmu.

el Harakah Jurnal Budaya Islam Vol. 23 No. 2, 2021 
